\title{
OTORITAS DAN LEGITIMASI KEDUDUKAN PEMIMPIN TRADISIONAL DI LOLODA MALUKU-UTARA (1808-1958)
}

\author{
Mustafa Mansur, Kunto Sofianto, dan Dade Mahzuni
}

Fakultas Sastra dan Budaya Universitas Khairun Ternate

Email:almansuriyah16@yahoo.co.id

\begin{abstract}
ABSTRAK. Studi mengenai kedudukan kepemimpinan tradisional di Loloda Maluku Utara pada masa kolonial hingga masa kemerdekaan Indonesia (1945-1958) merupakan studi untuk melihat aspek-aspek perubahan terhadap kedudukan pemimpin di Loloda sebagai akibat dari politik kolonial dan pengaruh Kesultanan Ternate. Berkaitan dengan hal tersebut, masalah yang diangkat adalah bagaimana kedudukan pemimpin tradisional di Loloda pada masa kolonial dan masa kemerdekaan Indonesia (1945-1958)? Adapun metode yang digunakan dalam penelitian adalah metode sejarah yang terdiri dari heuristik, kritik, interpretasi dan historiografi. Sementara konsep yang digunakan untuk menganalisis masalah adalah konsep kekuasaan, stratifikasi sosial dan legitimasi. Hasil penelitian menunjukkan bahwa kedudukan pemimpin tradisional di Loloda pada masa kolonial (1808-1909) mengalami degradasi dengan diubahnya status Kerajaan Loloda menjadi distrik oleh Pemerintah Hindia Belanda. Namun, pemimpinnya tetap memakai gelar raja (kolano) karena didukung oleh otoritas dan legitimasi tradisional, kharismatik serta sistem pewarisan kekuasaan (assigned status) dalam status sosialnya. Dalam konteks ini, Pemerintah Kolonial juga mengakui gelar raja (kolano) sebagai strategi membangun kekuasaanya di Loloda. Pengakuan Pemerintah Kolonial Belanda terhadap gelar raja (kolano) berakhir pada 1909 ketika raja dianggap mendalangi pemberontakan warganya yang mengakibatkan tewasnya Petugas Belanda yang bertugas di Loloda. Saat itulah kepala distrik ( hoofd district) memakai gelar sangaji. Pada masa kemerdekaan Indonesia, kedudukan pemimpin tradisional disimbolkan dengan mangkubumi (jogugu), namun masyarakat Loloda menganggapnya sebagai raja (kolano). Dengan demikian, kedudukan pemimpinnya terlembagakan berdasarkan otoritas dan legitimasi tradisional, kharismatik dan sistem pewarisan (assigned status).
\end{abstract}

Kata kunci: Loloda, kepemimpinan, otoritas, legitimasi.

\section{AUTHORITY AND LEGITIMATION OF POSITION TRADITIONAL LEADER IN LOLODA, NORTH MALUKU (1808-1945)}

\begin{abstract}
Study on the position of traditional leadership in Loloda, North Maluku from the colonial period to the early Indonesia (1945-1958) is the study to see the changing aspects on the position of leader in Loloda as the result of colonial politics and the influence of Ternate Monarch (Kesultanan Ternate). In relation to the issue, the problem raised is how is the position of traditional leader in Loloda in the colonial period to the early Indonesia (1945-1958)? The method employed for this research is the historical one which includes heuristics, criticism, interpretation, and historiography. The concepts used to analyze the issue are the concepts of power, stratification, social concept, and legitimation. The results show that the position of traditional leader in Loloda during the colonial period (1808-1909) was in degradation by the changing in the status of Loloda Monarch to a district by the East Indies Government. However, the leader remained with his monarchy title (kolano) because he was supported by traditional authority and legitimation, charisma, and also his social assigned status. In this context, the Colonial Government also acknowledged the kolano title as a strategy to establish their power in Loloda. The Netherland Colonial Government's acknowledgement to the kolano title ended in 1909 when the king was accused to be the man behind his people revolt which led to the death of a Colonial officer in duty in Loloda. That was also the time when the head of the district (hoof distrik) holds sangaji title. In the early Indonesia period, the position of traditional leader was symbolized as prime minister (mangkubumi, jogugu), but Loloda people considered him as the king (kolano). Thus, the position of the leader was institutionalized based on traditional authority and legitimation, charisma, and assigned status.
\end{abstract}

Key words: Loloda, leadership, authority, legitimation. 


\section{PENDAHULUAN}

\begin{abstract}
Penelitian mengenai kedudukan kepemimpinan dan kekuasaan tradisional di Indonesia cenderung dibatasi pada masa kolonial. Namun, pada masa kemerdekaan tampaknya belum banyak mendapat perhatian para peneliti. Perhatian penelitian pada periode kemerdekaan lebih cenderung pada masalah-masalah politik modern kontemporer. Padahal, banyak aspekaspek yang ditimbulkan akibat politik kolonial memiliki hubungan dengan sistem budaya pada masyarakat tertentu di masa kemerdekaan. Oleh karena itu, penelitian mengenai kedudukan pemimpin tradisional dari masa kolonial hingga masa kemerdekaan Indonesia menjadi perhatian dalam studi ini. Adapun daerah yang dilirik adalah Maluku Utara.
\end{abstract}

Di Maluku Utara, kepemimpinan dan kekuasaan tradisional dilembagakan dalam bentuk kerajaan atau kesultanan. Pelembagaan kepemimpinan dan kekuasaan itu telah ada sejak abad ke-13, dengan berdirinya enam kerajaan dengan kelompok-kelompok masyarakatnya. Enam kerajaan itu adalah Loloda, Moro ${ }^{1}$, Jailolo, Bacan, Tidore, dan Ternate (Hasan, 2001: 253; Abbas, 2007: 65). Dalam studi ini, Kerajaan Loloda dijadikan sebagai objek kajian.

Pada abad ke-19 hingga awal abad ke-20, status politik Loloda dianggap sebagai distrik dalam hierarki Pemerintahan Hindia Belanda. Namun, pemimpin Loloda tetap memakai gelar raja yang dalam istilah lokal disebut kolano (Leirissa, 1996: 96). Pada 1909, raja dipecat oleh Pemerintah Kolonial dan menggantikan gelar kepala distrik (hoofd district) dari kolano menjadi sangaji (Mansur, 2007: 65). Sangaji merupakan gelar yang melekat pada kepala distrik (hoofd district) pada umumnya di Halmahera.

Pemecatan raja dan perubahan gelar kepemimpinan berkaitan dengan pergolakan rakyat Loloda pada 14 Februari 1909 yang menyebabkan tewasnya Petugas Belanda di Loloda (Kolonial Verslag van Nederlandsch Oost Indie, 1909: 77). Kepemimpinan sangaji di Loloda berlangsung hingga masa kememerdekaan Indonesia (1958). Hal ini terlihat dari masihnya diberlakukannya pemerintahan distrik dan

1 Kerajaan Moro dianeksasi dan dileburkan ke dalam wilayah yurisdiksi Kesultanan Ternate pada 1575 (Amal, 2007: 210). keresidenan pada 1945 hingga 1958. Pada kurun waktu itu, Sultan Ternate, Tidore dan Bacan menjabat sebagai Residen Maluku Utara dalam periode yang berbeda. Pada 1945 hingga 1949, residennya dijabat oleh Sultan Ternate; 19491956 dijabat oleh Sultan Tidore; dan 1956-1958 dijabat Sultan Bacan (ANRI, 2008: 17).

Namun di Loloda, selain ada kedudukan kepala distrik atau sangaji, ada juga kedudukan Jogugu Loloda. Kedududukan jogugu ini dimulai sejak 1945 (Mansur, 2007: 74). Dalam struktur Pemerintahan Kesultanan di Maluku Utara, jogugu disamakan dengan wazir atau perdana menteri (Putuhena, 1983: 320; Muhammad, 2004: 50). Bisa juga disebut Mangkubumi. Akan tetapi, masyarakat Loloda ketika itu menganggap jogugu sebagai raja (kolano). Hal itu tergambar dari ungkapan jou atau jo'ou sebagai bentuk penghormatan kepada Jogugu Loloda. Kata jou dalam bahasa di Maluku Utara berarti "Yang Dipertuan Agung" (Hasan, 2001: 234). Ungkapan ini hanya bisa ditujukan kepada kolano (raja atau sultan). Ungkapan jou untuk Jogugu Loloda secara implisit mengandung makna raja (kolano). Selain ungkapan jou, makna raja terlihat juga dari atribut-atribut raja yang digunakan oleh jogugu dan perangkat pemerintahan tradisional seperti di Kesultanan Ternate. Aspek-aspek perubahan inilah yang menarik dan penting untuk diteliti.

Dengan mengacu pada uraian yang dikemukakan, dapatlah dirumuskan masalah sebagai berikut: Pertama, bagaimana kedudukan pemimpin tradisional di Loloda pada masa Kolonial Belanda? Kedua, bagaiamana kedudukan pemimpin tradisional di Loloda pada 1945 hingga 1958 ?

Untuk menjelaskan masalah tersebut, digunakan konsep kekuasaan, konsep stratifikasi sosial dalam hal ini status sosial, dan konsep legitimasi atau keabsahan. Konsep kekuasaan menjelaskan bahwa kekuasaan akan berjalan efektif apabila didukung oleh otoritas dan legitimasi. Dalam kaitan ini, Max Weber membagi otoritas menjadi tiga macam, yaitu otoritas yang bersifat tradisional, kharismatik dan legal-rasional. Otoritas tradisional berdasarkan kepercayaan bahwa tradisi lama serta kedudukan kekuasaan yang dilandasi oleh tradisi itu adalah wajar dan patut dihormati. Otoritas kharismatik berdasarkan kepercayaan anggota masyarakat terhadap kesaktian dan kekuatan mistik atau relegius 
seorang pemimpin. Otoritas legal-rasional berdasarkan kepercayaan terhadap tatanan hukum rasional yang melandasi kedudukan seorang pemimpin (Eissenstadt dalam Budiardjo (eds.), 1991: 15; Pababbari, 2010: 588).

Sementara dalam konsep status sosial menjelaskan bahwa seseorang atau kelompok memilki status sosial ${ }^{2}$ karena tiga hal. Pertama, ia menerima status sosialnya sebagai bentuk warisan (ascribed status). Kedua, seseorang memperoleh status sosial sebagai bentuk amanah (assigned status). Ketiga, status sosial yang dicapai atau diperoleh melalui suatu usaha (achieved status) (Pelly, 2005: 54; Tadjiri dalam Falah, 2009: 18-19;). Adapun konsep legitimasi atau keabsahan merujuk pada cara-cara yang dipakai para pemimpin negara untuk mendapatkan dukungan penduduk yang dikuasai atau kepercayaan sosial (Gilley dalam Nawawi, 2012: 22). Secara umum, ada lima strategi yang biasa digunakan untuk mendapatkan pengesahan atas legitimasi, yaitu: pertama, mobilisasi terencana di sektor perekonomian; kedua, penetapan jarak sosial antara penguasa dan yang dikuasai; ketiga, pengabsahan wewenang; keempat, konsolidasi wewenang dan kekuasaan; kelima sosialisasi politik penguasa terhadap rakyatnya (Kurtz dalam Falah, 2009: 21).

Dengan menggunakan konsep-konsep yang dikemukakan, berbagai aspek perubahan yang melekat pada kedudukan pemimpin tradisional di Loloda akan dapat dijelaskan.

\section{METODE}

Penelitian ini menggunakan metode sejarah yaitu proses menguji dan menganalisis secara kritis rekaman dan peninggalan agar peristiwa masa lampau dapat direkonstruksi secara imajinatif (Gottschalk dalam Falah, 2012: 117). Tahapan dalam metode sejarah meliputi, pertama, heuristik yakni mencari dan mengumpulkan sumber. Kedua, kritik yakni menyeleksi sumber, baik dari segi otensitasnya maupun kredibilitasnya. Ketiga, interpretasi yaitu menafsirkan dan memberi makna terhadap fakta sejarah. Keempat, historiografi yakni penulisan sejarah sebagai kisah yang logis dan sistematis.

2 Status sosial menurut Max Webber merupakan manifestasi dari stratifikasi sosial yang berkaitan dengan prinsip-prinsip yang dianut oleh komunitas dalam mengkonsumsi kekayaannya dan/atau gaya hidupnya (Singgih, 2010: 11).

\section{HASIL DAN PEMBAHASAN}

Kedudukan pemimpin tradisional di Loloda pada masa sebelum Kolonial Belanda memiliki akar sejarah yang panjang. Berdasarkan fakta historis, kedudukan pemimpin di Loloda memilki pengaruh yang cukup besar. Dikatakan demikan, karena Loloda merupakan salah satu Kerajaan Maluku yang diperkirakan berdiri pada pertengahan abad ke-13 (Hasan, 2001: 253). Hal ini sesuai dengan deskripsi dalam kitab Nagarakertagama Majapahit, yang mengungkapkan bahwa pada masa paling awal telah berkuasa seorang raja (kolano) di Loloda Halmahera sekaligus menandakan adanya kontak budaya antara Majapahit dan Daerah Maluku (Abdurrachman, 1978: 163; Iriyanto, 2006: 12). Masa paling awal disini setidaknya memberikan gambaran bahwa Kerajaan Loloda lebih dulu eksis dari Kerajaan Maluku lainnya.

Pada masa kekuasaan Verenigde Oost Indische Compagnie (VOC), Kerajaan Loloda memiliki pengaruh yang cukup berarti terhadap kekuasaan VOC di Maluku. Hal ini bisa dilihat dari Memorie van Overgave (MvO) Gubernur Robertus Padbrugge (1682), yang mengungkapkan keberadaan Lima Kerajaan Maluku dengan julukannya masing-masing. Kerajaan-kerajaan itu memilki hubungan formal dengan VOC. Kelima kerajaan dan julukan itu adalah: (1) Loloda, Ngara ma-beno (Wall of the Gate); Jailolo ${ }^{3}$, Jiko ma-kolano (Ruler of the Bay); Tidore, Kie makolano (Ruler of the Mountain); Ternate, Kolano Maluku (Ruler of Maluku); dan Bacan, Dehe makolano (Ruler of the Far End) (Andaya, 1993: 5; Amal, 2007: 206). Dari memori ini menunjukan bahwa kedudukan Penguasa Loloda relatif berdiri sejajar dengan Penguasa Maluku lainnya.

Status dan pengaruh politik Kerajaan Loloda baru mengalami degradasi pada masa Pemerintahan Hindia Belanda. Pada masa itu, Pemerintah Hindia Belanda membangun hubungan formal dengan Kesultanan Ternate, Tidore dan Bacan. Adapun Loloda dianggap sebagai distrik di bawah Kesultanan Ternate. Namun demikan, pemimpin Loloda tidak mau memakai gelar kepala distrik (sangaji), tetapi senantiasa memakai gelar raja atau kolano (van

3 Kerajaan Jailolo dianeksasi dan diubah statusnya menjadi distrik oleh Kesultanan Ternate pada 1686 dengan kepala distrik memakai titel sangaji (Paramita, 1983: 248; Putuhena, 1983: 315). 
Baarda, 1903: 320; Van Frassen, 1979: 115; Leirissa, 1996: 96). Ini menunjukkan upaya Penguasa Loloda mempertahankan integritas kerajaannya. Upaya Penguasa Loloda ini membuat Pemerintah Hindia Belanda menaruh perhatian lebih terhadap keadaan politik di Loloda. Hal ini bisa dilihat dari surat Gezagheebber ${ }^{4}$ pada 8 Desember 1808 yang memuat laporan tahunan kepada pejabat di atasnya, bahwa Kepala Distrik Loloda yang menggunakan gelar raja (kolano), memilki perangkat pemerintahan yang lengkap seperti pada Kerajaan Ternate. Selain ada seorang jogugu sebagai menteri utama, ada juga seorang kapita $l a u^{5}$ yang mengurusi masalah perang, seorang hukum yang menjadi utusan dengan rakyat, juga ada pejabat-pejabat di bawah lainnya seperti sowohi ${ }^{6}$ dan lain-lain (Leirissa, 1996: 9697). Laporan gezaghebber ini setidaknya memberikan catatan dalam pengambilan kebijakan Pemerintah Hindia Belanda terhadap keadaan politik di Loloda.

Catatan itu terbukti ketika Pemerintah Hindia Belanda membuat kontrak dengan Sultan Ternate pada 16 September 1817 untuk mengakui kekuasaan Hindia Belanda di Maluku, Raja Loloda turut dilibatkan dalam kontrak tersebut (ANRI, Koleksi Arsip Ternate). Ini menunjukkan Raja Loloda memiliki pengaruh dalam mengimbangi pengaruh Kesultanan Ternate terhadap Pemerintah Hindia Belanda.

Pada perkembangan kemudian, ketika Pemerintah Hindia Belanda kembali memperkuat kedudukannya di Maluku, dibuat lagi suatu perjanjian antara Gubernur Jenderal Van der Caplen dengan Sultan Ternate dan Tidore pada 8 April 1824. Sebagaimana halnya dengan perjanjian yang di buat pada 1817, semua penguasa di daerah taklukan Kesultanan Ternate juga turut dilibatkan dalam perjanjian tersebut. Namun dalam lampiran perjanjian itu, tidak terlihat adanya nama Raja Loloda (ANRI, Koleksi

4 Gezaghebber adalah penguasa atau kepala pemerintahan lokal setingkat distrik, tetapi dipegang oleh orang Belanda (Amal, 2007: 539).

${ }^{5}$ Kapita Lau adalah panglima perang kerajaan. Jabatan ini hanya bisa dijabat oleh seorang pangeran (prins) dan bangsawan utama lainnya (Putuhena. 1983: 317)

6 Sowohi adalah jabatan bagi orang yang mengawasi alat-alat kerajaan dan pelayan-pelayan yang bekerja di istana dan penanggung jawab atas apa yang harus dikerjakan sesuai permintaan sultan. Dengan perkataan lain, sowohi adalah jabatan humas dan protokoler istana (Putuhena, 1983: 322; Asyhari, 2008: 354).
Arsip Ternate). Meskipun demikan, secara de jure, Loloda tetap berada di bawah Ternate. Hal ini bisa dilihat dari transkip perjanjian itu pada prinsipnya mempertegas kekuasaan Hindia Belanda di Maluku yang mencakup wilayah Kesultanan Ternate, Tidore, dan Bacan. Adapun Loloda dimasukkan ke dalam wilayah Kesultanan Ternate. Pencaplokan wilayah Loloda ke dalam wilayah Kesultanan Ternate bisa saja mengacu pada perjanjian 1817, namun ketidakhadiran Raja Loloda dalam perjanjian itu, memberi kesan hubungan yang longgar antara Raja Loloda dan Sultan Ternate. Kondisi ini menunjukkan upaya Raja Loloda mempertahankan gengsinya sebagai raja, karena kehadiriannya justru disamakan dengan pejabat utama dan penguasa-penguasa lokal di bawah Kesultanan Ternate.

Akan tetapi pada perkembangan berikutnya, pengaruh Kesultanan Ternate semakin kuat terhadap kekuasaannya di Loloda. Kondisi ini dapat dilihat dari Memorie van Overgave J. Tobias (1857) dan C. Bosscher (1859), yang menggambarkan bahwa Loloda merupakan bagian dari Kesultanan Ternate. Dalam memori ini dikemukakan Sultan Ternate menerima dari Loloda 6 sampai 10 kati $^{7}$ Sarang Burung Walet $^{8}$ setiap tahun. Di samping itu orang Loloda harus menyediakan tiga orang penjaga gerbang kedaton dan seorang opas yang melayani sultan (ANRI, 1980: 30-31, 107-109).

Dari uraian di atas dapat dijelaskan bahwa Pemerintah Hindia Belanda dan Kesultanan Ternate memiliki otoritas untuk menjadikan Loloda sebagai distrik, karena memilki kekuasaan dan pengaruh yang besar di Maluku. Kekuasaan itu didukung oleh infrastruktur dan suprastruktur sistem politik ${ }^{9}$ yang memadai sehingga melahirkan legitimasi dari penguasa-penguasa pribumi di Maluku Utara termasuk Penguasa Loloda. Namun untuk tetap menjaga kepentingan itu, Penguasa Loloda tetap dibiarkan memakai gelar raja (kolano) sehingga masyarakat di Loloda dapat melihat bahwa posisi itu merupakan kepemimpinan yang dilandasi oleh tradisi

\footnotetext{
${ }^{7}$ Kati berarti ukuran yang berbobot $61 / 2$ ons. Lihat KBBI Online di situs Pusat Bahasa Kemdikbud, http://badanbahasa.kemdiknas.go.id/kbbi/index.php.

${ }^{8}$ Walet adalah burung layang-layang. Lihat KBBI Online di situs Pusat Bahasa Kemdikbud, http://badanbahasa.kemdiknas.go.id/kbbi/index.php.

9 Menurut Gabriel A. Almond, dalam sistem politik terdapat struktur-struktur politik atau lembaga-lembaga politik yang mempunyai fungsi-fungsi tertentu demi berjalannya proses politik (Sitepu, 2004: 163).
} 
sehingga wajar dan patut untuk dihormati. Ini menjadi penting bagi Pemerintah Hindia Belanda dan Kesultanan Ternate dalam upaya membangun hubungan dengan rakyat di Loloda. Dengan perkataan lain, hubungan antara yang berkuasa dan yang dikuasai berpangkal dari kontrak sosial-politik. Ide kontrak sosial ${ }^{10}$ mengandung arti pemberian amanat oleh rakyat kepada pemimpin untuk menjalankan kepemimpinannya atas kehendak dan persetujuan rakyat (Syamsuddin, 2004: 5). Selain itu, pengaruh Penguasa Loloda terhadap rakyatnya bisa jadi karena adanya otoritas kharismatik $^{11}$ yang dimilkinya. Hal ini mengacu pada pandangan bahwa dalam kepemimpinan tradisional atau kepemimpinan raja-raja pada umumnya dipengaruhi oleh kekuatan mistik atau supranatural. Dalam konteks ini, otoritas kharismatik yang mungkin dimiliki penguasa Loloda menjadi legitimasi bagi rakyatnya. Kondisi ini dimanfaatkan Pemerintah Hindia Belanda dan Kesultanan Ternate dalam membangun kekuasaannya di Loloda. Sementara bagi Penguasa Loloda, menganggap gelar raja (kolano) yang digunakannya merupakan bentuk warisan yang mengikat status sosialnya. Dengan kata lain, pewarisan jabatan itu dibenarkan oleh norma atau kebiasaan sejak kelahirannya (ascribed status). Dalam sistem feodal, umumnya melihat pergantian kekuasaan atau pemimpin berdasarkan garis keturunan. Pada konteks inilah, gelar raja (kolano) dianggap sebagai warisan dari raja sebelumnya.

Status kepemimpinan di Loloda mengalami suatu dinamika ${ }^{12}$ baru ketika datang orang-orang Baharu pada akhir abad ke-19. Orang-orang

10 Dalam kontrak sosial politik berlaku teori yang bertolak dari suatu asumsi bahwa hubungan antara yang berkuasa dan yang dikuasai bersifat kontraktual, yaitu dalam masa tertentu dan dengan kesepakatan-kesepakatan tertentu (Syamsuddin, 2004: 5).

11 kharisma pada dasarnya merupakan kemampuan pada diri seseorang, tetapi tidak selamnya dinisbahkan kepada orang. Dalam keadaan tertentu akan dapat dilakukan dipersonalisasi kharisma ke arah institusional, sehingga terjadi proses peralihan kharisma diri seseorang beralih ke kelembagaan. Dengan kata lain, melembagakan kharisma ke dalam institusi melalui suatu ritus atau upacara tertentu (Muchtarom, 2011: 935). Hal ini sesuai dengan pandangan yang mengatakan bahwa Kebanyakan dalam politik tradisional, organisasi diciptakan sebagai institusi pelayan raja atau kaisar (Martini, 2010: 69).

12 Dinamika adalah salah satu identitas kehidupan manusia baik secara individu, kelompok atau masyarakat. Dinamika masyarakat bersifat universal yakni terjadi pada setiap masyarakat di berbagai tempat, kondisi dan situasi (Ningrum, 2012: 47).
Baharu ini merupakan para perantauan yang datang dari Manggrai-Flores, Selayar dan Buton. Mereka dibajak oleh para bajak laut dan di daratkan di Utara Loloda. Orang-orang Baharu ini berada di bawah langsung perintah Raja Loloda tanpa intervensi Kesultanan Ternate (de Clerq; 1890: 74). Dengan keberadaan orang-orang Baharu yang berada di bawah kendali langsung Raja Loloda menunjukkan hubungan yang longgar antara Loloda dengan Ternate. Dalam konteks ini, otoritas tradisional dan kharismatik merupakan sarana dalam memberikan pengaruh kepada orang-orang Baharu. Kondisi ini dapat dijelaskan bahwa orang-orang Baharu mungkin melihat Raja Loloda sebagai pemegang otoritas tradisional di Loloda bukan Penguasa Ternate, sehingga mereka memberikan legitimasi kepada Raja Loloda. Selain itu, otoritas kharismatik Raja Loloda juga menjadi faktor yang mempengaruhi legitimasi orang-orang Baharu terhadap kepemimpinannya.

Status politik Loloda mengalami reduksi ketika terjadi pergolakan rakyat Loloda di bawah pimpinan Kapita ${ }^{13}$ Sikuru menetang sistem kerja paksa (rodl) dan sistem pajak diri (belasting) terhadap Pemerintah Kolonial pada 14 Februari 1909. Dalam pergolakan itu, seorang asisten dan dua Polisi Belanda yang bertugas di Loloda tewas. Pergolakan itu berhasil diredam setelah satu detasemen polisi dari Ternate tiba pada bulan itu juga. Akibat peristiwa itu, membuat raja, jogugu dan kapita lau dipecat dari jabatannya dan diasingkan ke Ternate karena dianggap mengetahui dan mendalangi peristiwa itu. Adapun nama rajanya adalah Kaicil Sjamsuddin (Kolonial Verslag van Nederlandsch Oost Indie, 1909: 77; Mansur, 2007: 63-64).

Dengan dipecatnya raja, jogugu dan kapita lau, sejak saat itu Pemerintah Hindia Belanda pun mengakhiri kedudukan raja di Loloda. Kepala Distrik Loloda kemudian ditempatkan oleh orangorang kepercayaan Pemerintah Hindia Belanda dan Kesultanan Ternate serta kepala distriknya (hoofd district) memakai gelar sangaji (Mansur, 2007: 65). Pemecatan raja, jogugu dan kapita lau serta pengasingan mereka ke Ternate menunjukkan upaya Pemerintah Hindia Belanda untuk menghindari adanya komunikasi raja

${ }^{13}$ Kapita adalah gelar pemimpin perang dan orang yang bertanggungjawab atas keamanan di suatu kampung (soa). Lihat glosarium dalam Muhammad, 2004: xvi; Amal, 2007: 540). 
dengan rakyat. Dengan demikian, penetapan jarak antara penguasa dan yang dikuasai merupakan cara atau strategi yang digunakan Pemerintah Hindia Belanda untuk mendapatkan legitimasi langsung dari rakyat. Adapun penempatan sangaji di Loloda merupakan upaya konsolidasi wewenang dan kekuasaan yang dilakukan oleh Pemerintah Hindia Belanda dan Kesultanan Ternate.

Selain itu, penempatan sangaji di Loloda menunjukkan upaya Pemerintah Hindia Belanda dan Kesultanan Ternate menyeragamkan status distrik yang ada di Halmahera. Sebagaimana dikemukakan sebelumnya, bahwa pada umumnya kepala distrik di Halmahera memakai gelar sangaji, kecuali Loloda memakai titel raja atau kolano. Dengan penyeragaman gelar kepala distrik, menunjukkan upaya Pemerintah Hindia Belanda dan Kesultanan Ternate, menerapkan prinsip kekuasaan legal-rasional. Adapun sangaji yang ditempatkan oleh Kesultanan Ternate menunjukkan status sosial kepemimpinannya berdasarkan amanah atau kepercayaan dari Kesultanan Ternate dan Pemerintah Hindia Belanda. Dengan demikian kepemimpinan berdasarkan otoritas dan legitimasai tradisonal, kharismatik dan sistem pewarisan (ascribed status), telah berubah menjadi kepemimpinan berdasarkan otoritas dan legitimasi legal-rasional dan amanah atau kepercayaan (assigned status). Kedudukan Sangaji Loloda berlangsung hingga 1958 ketika dilakukan perubahan status oleh Pemerintah Republik Indonesia. Perubahan itu seiring dengan pembentukan Daerah Swantara Tingkat II Maluku Utara, yang sekaligus mengakhiri status Keresidenan Maluku Utara (Lembaran Negara RI Tahun 1958 Nomor 111).

Ketika Maluku Utara masih berstatus keresidenan, Sultan Ternate, Tidore, dan Bacan memiliki peranan penting dalam menjalankan pemerintahan. Jika pada masa sebelum kemerdekaan, para residen dijabat oleh orang Belanda, maka pada masa kemerdekaan (19451958), residennya dijabat oleh sultan sebagai ex officio. Peranan ketiga Sultan Maluku itu (Ternate, Tidore, dan Bacan) merupakan impleimentasi dari kedudukan Daerah Maluku Utara dalam sistem ketatanegaraan Negara Indonesia Timur (NIT). Dalam pasal 13 dan 15 Undang-undang Dasar NIT, menyatakan bahwa Daerah Maluku Utara terdiri dari Daerah Swapraja Ternate, Tidore, dan Bacan (Abd. Rahman dan Abbas, 2011: 90).
Adapun sultan selaku ex officio Residen Maluku Utara adalah :

1. Residen Iskandar Muhammad Djabir Sjah (Sultan Ternate) 1945-1949;

2. Residen Zainal Abidin Sjah (Sultan Tidore) 1949-1956;

3. Residen Dede Muksin Usman Sjah (Sultan Bacan) 1956-1958

Sumber: ANRI, 2008: 17.

Dari kedudukan sultan selaku residen, menunjukkan bahwa sultan masih memilki kewenangan untuk mengangkat dan memberhentikan kepala distrik atau sangaji yang berada di bawah kesultanannya, tidak terkecuali bagi Distrik Loloda. Status Loloda sebagai distrik merupakan kelanjutan dari sistem Pemerintahan Hindia Belanda. Sebagaimana telah dikemukakan, Kepala Distrik Loloda mempertahankan gelar raja (kolano) dari 1808 hingga 1909, dan setelah itu gelar kolano diganti dengan gelar sangaji.

Perbedaan yang bisa diamati setelah kemerdekaan Indonesia adalah terdapat kedudukan Sangaji Loloda dan juga ada kedudukan Jogugu Loloda. Sangaji Loloda sebagai kepala pemerintahan distrik (hoofd district), sedangkan Jogugu Loloda sebagai simbol kepemimpinan kultural masyarakat Loloda. Kepemimpinan jogugu ini dimulai sejak September 1945 (Mansur, 2007: 74). Adapun jogugu saat itu adalah Kaicil Djami Bin Sjamsuddin (putera Kolano Syamsuddin) (Kolonial Verslag van Nederlandsch Oost Indie, 1909: 77; Mansur, 2007: 74)..

Dalam kedudukannya sebagai jogugu, ia dianggap juga sebagai raja (kolano) di Loloda. Hal ini tergambar dari ungkapan jou atau jo'ou sebagai bentuk penghormatan kepada Jogugu Loloda. Sebagaimana telah dikemukakan kata jou dalam bahasa di Maluku Utara berarti "Yang Dipertuan Agung". Ungkapan jou hanya bisa ditujukan kepada kolano (raja atau sultan). Namun terkadang jou dipercaya oleh sebagian masyarakat sebagai manifestasi anugerah yang datang dari Tuhan dan bermaksud untuk memperkokoh kewibawaan sultan, karena dengan adanya anugerah jou, sultan dikatakan berdaulat atas seluruh negeri dan rakyatnya (Muhammad, 2004: 43).

Ungkapan jou untuk Jogugu Loloda secara implisit mengandung makna raja (kolano). Makna raja (kolano) terlihat juga dari atribut-atribut raja 
yang digunakan oleh jogugu dan perangkat pemerintahan tradisional (bobato) seperti di Kesultanan Ternate. Adapun atribut-atribut raja yang digunakan jogugu disimbolkan dengan lambang-lambang seperti kostum dan payung kebesaran raja; kepemilikan tanah raja (aha kolano); kehendak mengeluarkan perintah dan kutukan (i'din dan bobeto) dan lain-lain. Sementara perangkat pemerintahan tradisional dapat dilihat dari adanya jabatan kapita lau (panglima utama perang), hukum soa-sio (menteri dalam negeri), tuli lamo (sekretaris besar), imam dan lain-lain (Mansur, 2007: 43-44).

Realitas di atas menunjukkan ketika status Kerajaan Loloda disetarakan setingkat distrik oleh Pemerintah Hindia Belanda dan Kesultanan Ternate pada abad ke-19, Penguasa Loloda tidak pernah menyandang gelar kepala distrik atau sangaji, tetapi senantiasa menggunakan titel raja atau kolano (Leirissa, 1996: 64). Selain itu, perangkat pemerintahan tradisional relatif memilki kesamaan sebagaimana yang dilaporkan gesaghebber kepada pejabat di atasnya dalam surat tertanggal 8 Desember 1808.

Dengan adanya kedudukan Jogugu Loloda setelah kemerdekaan Indonesia menunjukkan adanya legitimasi tradisional pada satu sisi, sedangkan pada sisi yang lain menunjukkan adanya legitimasi legal-rasional. Jogugu yang dianggap sebagai raja (kolano) menujukkan bentuk legitimasi tradisional, sedangkan kepala distrik (sangaji) merupakan bentuk legitimasi legal-rasional dalam pemerintahan setelah kemerdekaan Indonesia.

Legitimasi tradisional ini sekaligus menandakan era kebangkitan kerajaan Loloda. Jika sebelum 1909, kedudukan jogugu berada di bawah raja (kolano), pada masa kemerdekaan Indonesia, kedudukan jogugu menjadi yang utama dalam struktur kerajaan. Dengan kata lain, jogugu juga merangkap sebagai raja (kolano). Kedudukan jogugu ini tidak mengalami perubahan sering dengan perubahan status Distrik Loloda menjadi kecamatan pada 1958.

\section{SIMPULAN}

Kedudukan pemimpin tradisional di Loloda sebelum kemerdekaan Indonesia mengalami pasang-surut seiring dengan dinamika politik yang dihadapinya. Sebelum abad ke-19, kedudukan Penguasa Loloda memiliki pengaruh yang signifikan dalam mempertahankan integritas kerajaannya. Kondisi ini tergambar dari status Kerajaan Loloda yang berdiri sejajar dengan Kerajaan Ternate, Tidore, Bacan, dan Jailolo. Pada abad ke-19 hingga awal abad ke-20, status Kerajaan Loloda disamakan dengan distrik, namun pemimpinnya tetap mempertahankan gelar raja (kolano). Upaya mempertahankan gelar raja (kolano) merupakan bentuk dari otoritas tradisional dan kharismatik Penguasa Loloda. Adapun di pihak Pemerintah Hindia Belanda dan Kesultanan Ternate mengakui kedudukan dan gelar raja (kolano) untuk membangun hubungan dengan rakyat di Loloda. Sementara bagi Penguasa Loloda menganggap bahwa gelar raja (kolano) merupakan bentuk warisan dari status sosialnya dalam masyarakat (ascribed status).

Kedudukan dan pengaruh Raja Loloda berakhir ketika terjadi pergolakan di Loloda pada 14 Februari 1909 yang menyebabkan tewasnya Petugas Belanda di Loloda. Pada saat itu, raja dipecat dan diasingkan oleh Pemerintah Hindia Belanda ke Ternate sebagai upaya untuk menghindari komunikasi raja dengan rakyatnya. Adapun kedudukan sangaji yang muncul pada 1909, merupakan kepemimpinan amanah yang dipercayakan oleh Kesultanan Ternate dan Pemerintah Hindia Belanda. Penempatan sangaji ini sekaligus sebagai upaya Pemerintah Hindia Belanda dan Kesultanan Ternate untuk menerapkan prinsip kekuasaan legal-rasional.

Pada masa kemerdekaan Indonesia, atau sejak 1945 hingga 1958, kedudukan Jogugu Loloda dianggap juga sebagai raja (kolano). Bentuk penghormatan, atribut dan perangkat pemerintahan tradisional (bobato) merupakan simbol-simbol legitimasi terhadap kedudukan raja (kolano). Keadaan ini memperlihatkan hal yang sama pada masa Pemerintahan Hindia Belanda. Dengan demikian, kepemimpinan ini mencerminkan bentuk otoritas dan legitimasi yang bersifat tradisional dan kharismatik, serta sistem pewarisan jabatan dalam status sosialnya (ascribed status).

Adapun rekomendasi dari penelitian ini adalah agar Pemerintah Provinsi Maluku Utara, dan Pemerintah Kabupaten Halmahera Barat dapat merivitalisasi Keraton (kedaton) Loloda sebagai simbol peradaban masa lalu masyarakat Loloda dan sebagai wahana pembinaan dan pelestarian nilai-nilai sejarah, adat dan budaya di Loloda. 


\section{DAFTAR PUSTAKA}

\section{Sumber Resmi Tercetak}

Indonesia, Arsip Nasional. 1980. Memorie van Overgave J.H. Tobias (1857) dan Memorie van Overgave C. Boascher (1859). Jakarta: ANRI.

Indonesia, Arsip Nasional. "Deskripsi Perjanjian Pemerintah Hindia Belanda dengan Sultan Ternate dan Tidore pada 1817 dan 1824" dalam Koleksi Arsip Ternate. Jakarta: ANRI.

Indonesia, Arsip Nasional. 2008. Citra Maluku Utara dalam Arsip. Jakarta: ANRI.

Indonesia, DPR RI. Lembaran Negara Republik Indonesia Tahun 1958 Nomor 111. http://www.dpr.go.id/uu/uu1958/UU_1958 60.pdf, tanggal 26 Maret 2013 pkl. 13.17 WIB.

Indonesia, Pusat Bahasa. "Arti Istilah Kati dan Walet" dalam KBBI Online. Jakarta: Kemdikbud.http://badanbahasa.kemdiknas. go.id/kbbi/index.php.

Kolonial Verslag van Nederlandsch (Oost) Indie. 1909. Jakarta: Perpustakaan Nasional.

\section{Buku, Tesis, Skripsi, Laporan Penelitian dan Artikel}

Abdurrahman, Paramita. 1979. "Moluccan Responses to the First Intrusions of the West" dalam Haryati Soebadio \& Carien A. du Marchie Sarvaas (ed), Dynamics of Indonesia History. Amsterdam: NorttHolland Publishing Company.

1983. "Maluku, Portugal dan Spanyol Abad XVI dan XVII. Leknas LIPI Edisi Khusus. Vol. II, No. 2.

Andaya, Leonard Y. 1993. "Centers and Peripheries in Maluku". Cakalele Hawai of University. Vol. 4. https://scholarspace.manoa.hawaii.edu/bits tream/handle/10125, tanggal 1 Desember 2012, pkl. 13.46 WIB.

Abbas, Irwan. 2007. "Melacak Proses Penyebaran Islam di Timur Nusantara". Jurnal Tekstual Fakultas Sastra dan Budaya Universitas Khairun. Vol. 5, No. 7.
Amal, M. Adnan. 2007. Kepulauan RempahRempah Perjalanan Sejarah Maluku Utara Edisi Revisi. Makassar: Nala Cipta Litera.

Asyhary, Masyhud. 2008. "Status Tanah-Tanah Kesultanan Ternate dalam Perspektif Tanah Nasional". Mimbar Hukum UGM. Vol. 20 No. 2.

Abd. Rahman dan Abbas, Irwan. 2011. "Sultan Zainal Abidin Syah (1912-1967); Sosok Pemimpin dan Pejuang Pembebasan Irian Barat". Pendidikan dan Humaniora Forum Komunikasi IImiah Dosen FKIP Universitas Jember. Vol. 29 No. 1.

Budiardjo, Miriam (eds.). 1991. Aneka Pemikiran tentang Kuasa dan Wibawa. Jakarta: Sinar Harapan.

de Clerq, F. S. A. 1999. Ternate: The Residency and Its Sultanate, Translated: from the Dutch by Paul Michael Taylor and Marie N. Richards. Woshington D.C: Smithsonian Institution Libraries.

Falah, Miftahul. 2009. "Perubahan Sosial di Kota Tasikmalaya (1820-1942)". Tesis. Bandung: Universitas Padjadjaran.

, 2012. "Pers di Kota Tasikmalaya". Sosiohumaniora Unpad. Vol. 14, No. 2.

Hasan, Abdul Hamid. 2001. Aroma Sejarah dan BUdaya Ternate. Jakarta: Antara Pustaka Utama.

Iriyanto, Nurachman. 2006. "Dinamika Arkeologi dan Peluang Pemanfaatannya di Maluku Utara". Jurnal Tekstual Fakultas Sastra dan Budaya Universitas Khairun. Vol. 4, No. 6.

Leirissa, R.Z. 1996. Halmahera Timur dan Raja Jailolo. Jakarta: Balai Pustaka.

Muhammad, Syahril. 2004. Kesultanan Ternate Sej. Sosial ekonomi dan Politik. Yokyakarta: Ombak.

Mansur, Mustafa. 2007. "Loloda dan Integritas Kesultanan Ternate". Skripsi. Ternate: Prodi Ilmu Sejarah Universitas Khairun. 
Martini, Rina. 2010. "Politisasi Birokrasi di Indonesia". Politika Jurnal IImu Politik Undip. Vol. 1, No. 1.

Muchtarom, H. Zaini. 2011. "Konsep Max Weber tentang kepemimpinan Kharismatik". Manajemen Bisnis Syariah UNIBA Surakarta. No. 2 Tahun ke V.

Nawawi, Juanda. 2012. "Membangun Kepercayaan dalam Mewujudkan Good Governance". Jurnal IImiah IImu Pemerintahan Unhas. Vol. 1, No. 3.

Ningrum, Epom. 2012. "Dinamika Masyarakat Tradisional Kampung Naga di Kabupaten Tasikmalaya". Mimbar Unisba, Vol. XXVIII, No. 1.

Putuhena, Saleh. 1983. "Struktur Pemerintahan Kesultanan Ternate dan Agama Islam". Leknas LIPI Edisi Khusus. Vol. II, No. 2.

Pelly, Usman. 2005. "Pengukuran Intensitas Konflik dalam Masyarakat Majemuk". Etnovisi Jurnal Antropologi Sosial Budaya FISIP USU. Vol. 01, No. 02.

Pababbari, Musafir. 2010. "Patronase Agama dalam Kehidupan Politik". Annual Conference on Islamic Studies (ACIS) Ke 10.
Syamsuddin, Din. 2004."Antara yang berkuasa dan yang Dikuasai Refleksi Atas Pemikiran dan Praktek Politik Islam". Jurnal I/miah Forum Pangaji Lembaga Kajian dan Pemikiran Pendidikan Islam untuk Masa Depan STAIN Ternate. Vol. 1 No. 2.

Sitepu, P. Anthonius. 2004. "Transformasi Kekuatan-kekuatan Politik Suatu Studi Teori Kelompok dalam Konfigurasi Politik Sistem Politik Indonesia". Jurnal Pemberdayaan Komunitas USU. Vol. 3, No. 3.

Singgih, Doddy Sumbodo. 2010. "Prosedur Analisis Stratifikasi Sosial dalam Perspektif Sosiologi". Masyarakat Kebudayaan dan Politik Unair. Vol. 20, No. 1.

Van Fraassen, Ch. F. 1978. "Types of SocioPolitical Structure in North-Halmaheran History". Majalah IImu-IImu Sastra Indonesia. Jilid II No. 2 hal. 115.

Van Baarda, M.J. 1904. "Het Loda'sch, in vergelijking met het Galala'sch dialect op Halmaheira". Bijdragen tot de Taal-Land-en Volkenkunde, Vol. 56, No. 1. http://www.kitlvjournals.nl/index.php/btlv/a rticle/viewFile/6762/7529, tanggal 20 November 2012, pkl. 19.48 WIB. 